Jurnal Progres Ekonomi Pembangunan (JPEP)

Volume 5, Nomor 1. Tahun 2020

Page: $58-70$

http://ojs.uho.ac.id/index.php/JPEP

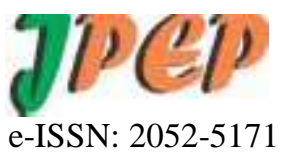

\title{
PENGARUH DAU, PAD, JENIS DAN LETAK PEMERINTAHAN TERHADAP PERILAKU OPORTUNISTIK PENYUSUN ANGGARAN DI KABUPATEN/KOTA SE-SULAWESI TENGGARA
}

\author{
Yusuf Jaya Saputra \\ Program Ilmu Ekonomi Pascasarjana Universitas Halu Oleo Kendari \\ Email: yusufjayasaputra@yahoo.co.id \\ Rosnawintang \\ Fakultas Ekonomi dan Bisnis Universitas Halu Oleo Kendari \\ Email: nanarosnawintang@gmail.com \\ Nasrullah Dali \\ Fakultas Ekonomi dan Bisnis Universitas Halu Oleo Kendari \\ Email: nasrullahdali19@gmail.com
}

\begin{abstract}
ABSTRAK
Tujuan dari penelitian ini adalah untuk mendapatkan bukti empiris pengaruh DAU, PAD dan Jenis dan Letak Pemerintahan dan Pinjaman Daerah pada Perilaku Oportunistik Penyusun Anggaran Di Kabupaten/Kota SeSulawesi Tenggara. Jenis data dalam penelitian ini terdiri atas sumber data sekunder runtut waktu (time series) dari tahun 2011-2016 yang bersumber dari Biro Keuangan Sekretariat Daerah Provinsi Sulawesi Tenggara, Badan Pusat Statistik (BPS) Sulawesi Tenggara, Kajian Ekonomi dan Keuangan Regional Provinsi Sulawesi Tenggara Kantor Perwakilan Bank Indonesia Provinsi Sulawesi Tenggara tahun 2011 - 2016 dan situs Direktorat Jendral Keuangan Daerah Kementerian Keuangan. Untuk analisis digunakan alat analisis regresi data panel dan diolah menggunakan E-Views 10. Hasil pengujian hipotesis menunjukkan bahwa variabel DAU dan PAD berpengaruh positif pada perilaku oportunistik penyusun anggaran, variabel JENIS DAN LETAK memiliki pengaruh yang tidak signifikan dan juga berpengaruh negatif terhadap OPA.
\end{abstract}

Kata Kunci: Anggaran, Legislatif, Perilaku Oportunistik.

\begin{abstract}
The purpose of this study is to obtain empirical evidence of the influence of DAU, PAD and the Types and Locations of Government and Regional Loans on the Opportunistic Behavior of Budget Compilers in Regencies / Cities in Southeast Sulawesi. The type of data in this study consists of time series of secondary data sources from 2011-2016 sourced from the Southeast Sulawesi Regional Secretariat Financial Bureau, Central Sulawesi Statistics Agency (BPS), Southeast Sulawesi Regional Economic and Financial Study Office Representative of Bank Indonesia, Southeast Sulawesi Province in 2011-2016 and the website of the Directorate General of Regional Finance, Ministry of Finance. For the analysis, panel data regression analysis tools are used and processed using E-Views 10. Hypothesis testing results indicate that the DAU and PAD variables have a positive effect on the opportunistic behavior of the budget compilers, the TYPE AND LAY variables have insignificant influence and also have a negative effect on the OPA.
\end{abstract}

Keywords: Budget, Legislature, Opportunistic Behavior.

\section{PENDAHULUAN}

Permasalahan pada penyusunan anggaran timbul ketika pihak - pihak yang terlibat berupaya untuk memanfaatkan peluang agar kepentingan pribadi dan kelompoknya dapat diakomodir dalam APBD (Raghunandan et al., 2012; Suryarini, 2012; Radebe and Radebe, 2014). Kebijakan anggaran menjadi ajang perebutan kepentingan oleh berbagai pihak, baik pemerintah, legislatif, partai politik, pengusaha, organisasi masyarakat, maupun rakyat kecil (Sujaie, 2013). Berbagai modus perilaku oportunistik yang sering terjadi seperti menetapkan alokasi anggaran yang dimodifikasi untuk memenuhi kepentingan politik dan kepentingan individu, memasukkan usulan proyek-proyek besar yang menguntungkan salah satu pihak dalam perencanaan anggaran, serta sikap cenderung 
Jurnal Progres Ekonomi Pembangunan (JPEP)

Volume 5, Nomor 1. Tahun 2020

Page: $58-70$

http://ojs.uho.ac.id/index.php/JPEP

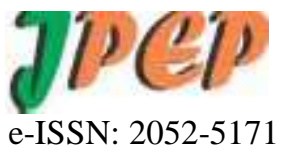

lebih memperjuangkan realisasi penetapan anggaran atas proyek-proyek yang mudah dikorupsi dengan harapan mendapatkan kompensasi fee project yang cukup besar (Jumaidi, 2014).

Penelitian Sujaie (2013) menunjukkan bahwa praktek perilaku oportunistik eksekutif dalam kebijakan anggaran terjadi karena dua faktor pendorong: Pertama, anggapan bahwa eksekutif merupakan pelaksana semua fungsi pemerintah daerah yang telah berhubungan langsung dengan masyarakat dalam waktu sangat lama; dan Kedua, eksekutif mempunyai akses informasi yang besar dalam konteks penyusunan anggaran. Sedangkan perilaku oportunistik legislatif didorong oleh adanya keunggulan kekuasaan (discretionary power) dalam konteks memutuskan anggaran. Faktor inilah yang mendorong legislatif untuk melakukan; Pertama, berusaha memengaruhi eksekutif untuk memaksimumkan anggaran pada program-program tertentu yang dapat memuluskan jalan bagi seorang legislator untuk dapat terpilih kembali dalam pemilu berikutnya; Kedua, mendorong eksekutif untuk mengajukan anggaran yang dapat dengan mudah diserap oleh konstituennya dan tidak melalui prosedur birokrasi yang rumit.

Fenomena perilaku penyusun anggaran sangat menarik untuk diteliti lebih lanjut, karena meskipun aturan formal tentang mekanisme penyusunan APBD telah dirancang sedemikian rupa, namun pada prakteknya masih terjadi beberapa penyimpangan. Meningkatnya kasus korupsi merupakan salah satu indikasi terjadinya perilaku oportunistik yang dilakukan penyusun anggaran (Mauro,1998). Sejalan dengan hal tersebut, Sujaie (2013) menegaskan bahwa peningkatan belanja hibah dan bantuan sosial juga menunjukkan telah terjadi perilaku oportunistik penyusun anggaran.

Sepanjang tahun 2015 sebanyak 57 kasus korupsi di Sulawesi Tenggara yang terdeteksi melalui pencarian media online, media cetak dan lain-lain. Adapun daerah yang paling banyak melakukan tindakan korupsi yakni Kabupaten Muna, Kota Kendari, Kolaka Utara, Disusul dengan Kabupaten Konawe Selatan, Bombana dan Kolaka. Daerah yang paling tinggi nilai nominal uang yang di korupsi di Sulawesi Tenggara yakni Pemerintah Provinsi Sulawesi Tenggara, Konawe Selatan, Kota Baubau, Bombana, dan Muna.

Penelitian sebelumnya (Abdullah dan Asmara, 2006; Abdullah, 2012; Oktririniatmaja, 2011; Suryarini, 2012; Sularso dkk., 2014) menunjukkan bahwa DAU, PAD dan SiLPA berpengaruh positif terhadap perilaku oportunistik penyusunan anggaran. Penelitian tentang perilaku oportunistik penyusun anggaran sebelumnya, lebih fokus pada perilaku legislatif yang cenderung mempengaruhi alokasi anggaran untuk kepentingan politik dengan meningkatkan anggaran untuk belanja infastruktur dan belanja DPRD. Namun mengamati fenomena yang terjadi terkait proses penyusunan APBD yang merupakan proses bersama antara legislatif dan eksekutif, peneliti tertarik untuk meneliti perilaku oportunistik yang terjadi akibat interaksi antara kedua pihak yang didasari adanya hubungan keagenan.

Berdasarkan uraian latar belakang di atas dan berbagai fenomena serta kesenjangan penelitian terdahulu yang telah dijelaskan sebelumnya, peneliti tertarik penelitian dengan judul "Pengaruh DAU, PAD, Jenis dan Letak Pemerintahan Terhadap Perilaku Oportunistik Penyusun Anggaran Di Kabupaten/Kota Se-Sulawesi Tenggara". Penelitian ini bertujuan untuk menganalisis dan mengetahui pengaruh DAU, PAD dan Letak Pemerintahan terhadap perilaku oportunistik.

\section{TINJAUAN PUSTAKA DAN PENGEMBANGAN HIPOTESIS}

Teori agensi dalam konteks pemerintahan, dipandang dalam perspektif bahwa pemerintah daerah adalah agent bagi publik atau masyarakat, sehingga dalam hal ini masyarakat atau publik diposisikan sebagai principal. Pelaksanaan berbagai tugas pemerintah merupakan bentuk nyata dari pelaksanaan tugas dan kewenangan yang dimiliki berdasarkan legitimasi dari publik, namun dalam pelaksanaannya sering terjadi ketidakseimbangan informasi antara agent (pemerintah) yang 
Jurnal Progres Ekonomi Pembangunan (JPEP)

Volume 5, Nomor 1. Tahun 2020

Page: $58-70$

http://ojs.uho.ac.id/index.php/JPEP

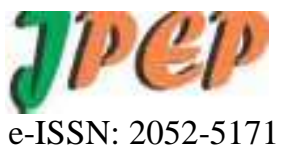

mempunyai akses langsung terhadap informasi dengan pihak principal (masyarakat). Adanya informasi yang asimetri inilah yang menjadikan para agent berlaku oportunis atas peluang yang ada dan dapat mengarah pada terjadinya kecurangan ( $f r a u d)$ serta penyelewengan.

Eisenhardt (1989) menggunakan tiga asumsi sifat dasar manusia guna menjelaskan tentang teori keagenan yaitu: (1) manusia pada umumnya mementingkan diri sendiri (self interest), (2) manusia memiliki daya pikir terbatas mengenai persepsi masa mendatang (bounded rationality), dan (3) manusia selalu menghindari resiko (risk averse). Berdasarkan asumsi sifat dasar manusia tersebut, manajer sebagai manusia kemungkinan besar akan bertindak mengutamakan kepentingan pribadinya. Hal ini menimbulkan adanya konflik kepentingan antara principal dan agent. Principal memiliki kepentingan untuk memaksimalkan keuntungan mereka sedangkan agent memiliki kepentingan untuk memaksimalkan pemenuhan kebutuhan ekonomi dan psikologisnya.

Implikasi teori keagenan muncul dalam proses penyusunan anggaran dilihat dari dua perspektif yaitu hubungan antara rakyat dengan legislatif, dan legislatif dengan eksekutif. Ditinjau dari perspektif hubungan keagenan antara legislatif dengan eksekutif, eksekutif adalah agent dan legislatif adalah principal (Halim dan Abdullah, 2006). Apabila dilihat dari perspektif hubungan keagenan legislatif dengan rakyat, pihak legislatif adalah agent yang membela kepentingan rakyat (principal), akan tetapi tidak ada kejelasan mekanisme dan pengaturan serta pengendalian dalam pendelegasian kewenangan rakyat terhadap legislatif. Hal inilah yang seringkali menyebabkan adanya distorsi anggaran yang disusun oleh legislatif sehingga anggaran tidak mencerminkan alokasi pemenuhan sumber daya kepada masyarakat, melainkan cenderung mengutamakan selfinterest para pihak legislatif tersebut. Jika hal ini terjadi, besar kemungkinan anggaran yang disahkan adalah alat untuk melancarkan aksi pencurian hak rakyat atau sering dikenal dengan istilah korupsi (Mauro, 1998; Keefer and Khemani, 2003).

Hubungan keagenan di pemerintahan antara legislatif dan eksekutif menunjukkan posisi legislatif sebagai prinsipal dan eksekutif adalah agen (Halim dan Abdullah, 2006; Latifah, 2010; Abdullah, 2012). Hubungan antara prinsipal dan agen senantiasa menimbulkan masalah keagenan yang disebut agency problems (Lupia and McCubbins, 2000). Johnson (1994) dalam Abdullah dan Asmara (2006) menyebut hubungan eksekutif atau birokrasi dengan legislatif atau kongres dengan nama self-interest model. Dalam hal ini, legislators ingin dipilih kembali, birokrat ingin memaksimumkan anggarannya, dan konstituen ingin memaksimumkan utilitasnya. Agar terpilih kembali, legislators mencari program dan proyek yang membuatnya populer di mata konstituen. Birokrat mengusulkan program-program baru karena ingin agency-nya berkembang dan konstituen percaya bahwa mereka menerima manfaat dari pemerintah tanpa harus membayar biayanya secara penuh. Hal ini menunjukkan bahwa baik eksekutif maupun legislatif berupaya untuk memaksimalkan dan memanfaatkan perannya dalam penyusunan anggaran demi memperoleh keuntungan individual maupun kepentingan kelompok yang cenderung akan menimbulkan kerugian bagi rakyat.

Lupia and McCubbins (2000) menyatakan bahwa warganegara adalah principal yang menunjuk perwakilannya untuk melayani mereka sebagai agen di parlemen, sementara Andvig et al. (2001) menyebutkan voters adalah prinsipal dari parlemen. Dalam hal pembuatan kebijakan, Hagen (2002) berpendapat bahwa hubungan prinsipal-agen yang terjadi antara pemilih (voters) dan legislatif pada dasarnya menunjukkan bagaimana voters memilih politisi untuk membuat keputusan-keputusan tentang belanja publik untuk mereka dan mereka memberikan dana dengan membayar pajak. Ketika legislatif kemudian terlibat dalam pembuatan keputusan atas pengalokasian belanja dalam anggaran, maka mereka diharapkan mewakili kepentingan atau preferensi prinsipal atau pemilihnya. Pada kenyataannya legislatif sebagai agen bagi publik tidak selalu memiliki kepentingan yang sama dengan publik (Abdullah dan Asmara, 2006). 
Jurnal Progres Ekonomi Pembangunan (JPEP)

Volume 5, Nomor 1. Tahun 2020

Page: $58-70$

http://ojs.uho.ac.id/index.php/JPEP

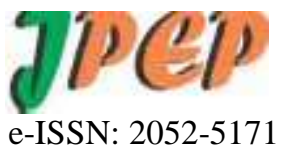

Studi Abdullah (2012) menemukan adanya perbedaan preferensi antara eksekutif dan legislatif dalam pengalokasian spread PAD ke dalam belanja sektoral. Alokasi untuk infrastruktur dan DPRD mengalami kenaikan, tapi alokasi untuk pendidikan dan kesehatan justru mengalami penurunan. Abdullah (2012) menemukan bahwa power legislatif yang sangat besar menyebabkan diskresi atas penggunaan PAD tidak sesuai dengan preferensi publik. Penelitian Sularso dkk. (2014) serta Abdullah dan Asmara (2006) menunjukkan bahwa semakin besar PAD maka perilaku oportunistik penyusunan anggaran akan semakin besar.

Tujuan dari dana alokasi umum adalah untuk pemerataan keuangan antar daerah. Penerimaan DAU membuka ruang bagi legislatif untuk memaksimalkan utilitasnya dengan merekomendasikan eksekutif agar mengalokasikan anggaran untuk kegiatan atau proyek-proyek yang menguntungkan legislatif (Abdullah,2012). Transfer dari pemerintah pusat memiliki keterkaitan sangat erat dengan belanja pemerintah daerah. Oktririniatmaja (2011) menyatakan bahwa DAU berpengaruh positif terhadap peningkatan alokasi belanja modal.

Kecenderungan perilaku oportunistik yang dilakukan politisi pada level pemerintah daerah tidak dapat dilakukan pada sisi pendapatan, karena pendapatan daerah sebagian besar bersumber dari dana transfer pemerintah pusat (Bartolini and Santolini, 2007). Lebih lanjut disebutkan bahwa kondisi ini menyebabkan perilaku oportunistik yang dilakukan politisi hanya dapat memengaruhi sisi belanja dalam APBD. DAU yang diterima daerah dapat mengakibatkan perubahan alokasi anggaran dalam APBD (Maryono, 2013).

Mardiasmo (2002) menyatakan bahwa pendidikan dan kesehatan merupakan bentuk pelayanan publik yang paling mendasar, namun jenis belanja tersebut tidak dapat memberikan peluang untuk korupsi, sehingga anggaran pendidikan, kesehatan, dan sosial akan diperkecil (Mauro, 1998). Studi Mauro (1998) menunjukkan bahwa jenis-jenis belanja pemerintah berupa belanja barang atau pelayanan untuk program-program dan kegiatan yang sulit untuk dimonitor orang lain, membuka peluang terjadinya perilaku oportunistik. Hasil penelitian ini dikuatkan oleh Tanzi and Davoodi (2002) yang mengemukakan bahwa belanja investasi publik lebih disukai karena dapat memberikan komisi lebih besar daripada belanja untuk pelayanan sosial, pendidikan, dan kesehatan. Jenis dan Letak Pemerintahan dapat di samakan sebagai status daerah, dimana pandangan bahwa status daerah mempengaruhi kelengkapan pengungkapan dikarenakan adanya perbedaan karakteristik masyarakat dan struktur pendapatan antar daerah. Perbedaan ini dapat berimplikasi pada kontrol sosial yang berbeda pula (Abdullah, 2004).

\section{Kerangka Konsep Dan Hipotesis}

Kerangka konsep variabel penelitian dibuat berdasarkan hasil penggabungan variabel independen dan variabel dependen. Dalam penelitian ini, yang menjadi variabel independen adalah $D A U, P A D$ dan Jenis dan Letak Pemerintahan. Sedangkan yang menjadi variabel dependen adalah Perilaku Opportunistik Penyusun Anggaran. Sehingga dapat digambarkan kerangka konsep variabel penelitian sebagai berikut:

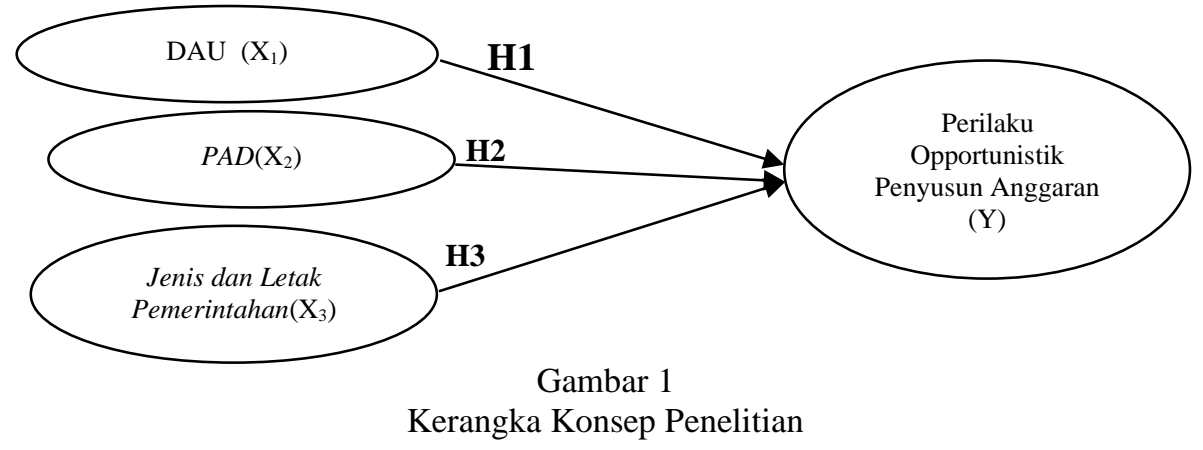

Corresponding Author: Yusuf Jaya Saputra 61 
Jurnal Progres Ekonomi Pembangunan (JPEP)

Volume 5, Nomor 1. Tahun 2020

Page: $58-70$

http://ojs.uho.ac.id/index.php/JPEP

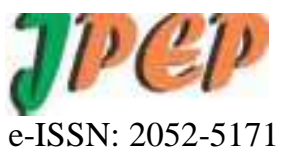

Tujuan dari Dana Alokasi Umum adalah untuk pemerataan keuangan antar daerah. Penerimaan DAU membuka ruang bagi legislatif untuk memaksimalkan utilitasnya dengan merekomendasikan eksekutif agar mengalokasikan anggaran untuk kegiatan atau proyek-proyek yang menguntungkan legislatif (Abdullah, 2012). Transfer dari pemerintah pusat memiliki keterkaitan sangat erat dengan belanja pemerintah daerah. Oktririniatmaja (2011) menyatakan bahwa DAU berpengaruh positif terhadap peningkatan alokasi belanja modalKecenderungan perilaku oportunistik yang dilakukan politisi pada level pemerintah daerah tidak dapat dilakukan pada sisi pendapatan, karena pendapatan daerah sebagian besar bersumber dari dana transfer pemerintah pusat (Bartolini and Santolini, 2007). Lebih lanjut disebutkan bahwa kondisi ini menyebabkan perilaku oportunistik yang dilakukan politisi hanya dapat memengaruhi sisi belanja dalam APBD. DAU yang diterima daerah dapat mengakibatkan perubahan alokasi anggaran dalam APBD (Maryono, 2013). Berdasarkan kajian empiris di atas, maka peneliti merumuskan hipotesis penelitian sebagai berikut:

H1 : Terdapat pengaruh positif signifikan DAU terhadap Perilaku Oportunistik Penyusun Anggaran

H2 : Terdapat pengaruh positif signifikan PAD terhadap Perilaku Oportunistik Penyusun Anggaran.

H3 : Terdapat pengaruh positif signifikan Letak Pemerintahan terhadap Perilaku Oportunistik Penyusun Anggaran.

\section{METODE PENELITIAN}

Jenis penelitian merupakan Penelitian kuantitatif. Penelitian berlangsung pada 12 (dua belas) Kabupaten/Kota se-Sulawesi Tenggara dari 17 (tujuh belas) Kabupaten/Kota se-Sulawesi Tenggara untuk menganalisis data APBD pada kurun waktu 2011 - 2016.

Definisi operasional yang digunakan adalah sebagai berikut:

1. Pengukuran kinerja OPA di dalam penelitian ini menggunakan anggaran biaya tak langsung yang dialokasikan dari APBD Kabupaten/Kota di Sulawesi Tenggara yaitu:Spread = APBD tahun berjalan (t) - APBD tahun sebelumnya (t-). Nilai OPA menunjukkan adanya perilaku penyusun anggaran yang memanfaatkan kekuasaan dan kewenangannya untuk mempengaruhi kebijakan pengalokasian anggaran sesuai dengan preferensi diri atau kelompoknya, sehingga nilai OPA menggambarkan besaran self-interest penyusun anggaran (Abdullah, 2012).

2. Pengukuran DAU dengan menggunakan spread Dana Alokasi Umum (DAU) dari APBD tahun berjalan (t) ke APBD tahun sebelumnya (t-1) (Sularso dkk., 2014).

3. Pengukuran $\mathrm{PAD}$ menggunakan spread $\mathrm{PAD}(\triangle \mathrm{PAD})$ adalah perubahan naik atau turunnya PAD dari APBD tahun berjalan (t) ke APBD tahun sebelumnya (t-1) (Abdullah, 2012). PAD = PAD APBD (t) - APBD ( $\mathrm{t}-1)$

4. Jenis dan Letak Pemerintahan diukur dengan menggunakan skor. Jika status daerah adalah Kabupaten, diberi kode 1 (satu) dan jika status daerah adalah Kota, diberikan kode 2 (dua). Variabel ini digunakan dalam penelitian Abdullah, (2004) dan Retnoningsih (2009).

Alat analisis yang digunakan adalah analisis regresi data panel. Data panel merupakan gabungan antara data silang (cross section) dengan data runtut waktu (time series). Untuk memilih model yang paling tepat digunakan dalam mengelola data panel,terdapat beberapa pengujianyangdapat dilakukanyakni:

1. Chow testatau Likelyhood test

2. Hausman test

3. Langrange Multiplier (LM) 
Jurnal Progres Ekonomi Pembangunan (JPEP)

Volume 5, Nomor 1. Tahun 2020

Page: $58-70$

http://ojs.uho.ac.id/index.php/JPEP

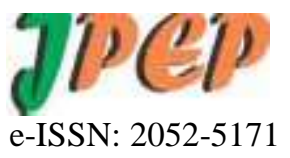

\section{Analisis Koefisien Determinasi (R-Square)}

Uji koefisien determinasi dilakukan untuk mengetahui seberapa besar variabel independen dapat menjelaskan variabel dependen. Dianjurkan untuk menggunakan nilai adjusted $R$-Squares dalam mengevaluasi model regresi, dimana nilainya dapat naik atau turun apabila satu variabel independen ditambahkan kedalam model.

Uji Signifikasi Simultan (Uji Statistik F)

Uji $\mathrm{F}$ bertujuan untuk mengetahui apakah semua variabel independen yang dimasukkan dalam model regresi mempunyai pengaruh simultan (bersama-sama) terhadap variabel dependen ataukah tidak. Cara untuk menguji yaitu dapat dilakukan dengan membandingkan $\mathrm{F}_{\text {hitung }}$ dengan $\mathrm{F}_{\text {tabel }}$ dan nilai t-sig dengan $\alpha: 0,05$. Apabila $\mathrm{F}_{\text {hitung }}>\mathrm{F}_{\text {tabel }} \mathrm{F}$-sig $<$ dari $\alpha: 0,05$, maka maka dapat disimpulkan bahwa semua variabel independen secara simultan berpengaruh signifikan terhadap variabel dependen.

\section{Uji Signifikan Parameter Individual (Uji t)}

Uji t digunakan untuk mengetahui pengaruh variabel-variabel $\mathrm{X}$ terhadap variabel $\mathrm{Y}$. Uji $\mathrm{t}$ dapat dilakukan dengan membandingkan antara $t_{\text {hitungdengan }} t_{\text {tabel }}$ dan nilai $t$-sig dengan $\alpha: 0,05$. Apabila $t_{\text {hitung }}>\mathrm{t}_{\text {tabel }} \mathrm{t}$-sig $<$ dari $\alpha: 0,05$, maka diterima $\mathrm{H} 1$ atau tolak H0. Sebaliknya, apabila $\mathrm{t}_{\text {hitung }}$ $<\mathrm{t}_{\text {tabel }} \mathrm{t}$-sig $>$ dari $\alpha$ : 0,05 maka tolak H1 atau terima H0.

\section{HASIL PENELITIAN DAN PEMBAHASAN}

\section{Hasil Penelitian}

\section{Pengujian menggunakan Common Effect Models (CEM)}

Dalam pendekatan estimasi Common Effect Models, intersep dan slope adalah tetap sepanjang waktu dan individu, adanya perbedaan intersep dan slope diasumsikan akan dijelaskan oleh variabel gangguan (error atau residual), hal tersebut dapat dilihat pada tabel berikut:

\section{Tabel 1}

Hasil Estimasi Common Effect Models (CEM)

\begin{tabular}{lrrrr}
\hline \hline \multicolumn{1}{c}{ Variable } & \multicolumn{1}{c}{ Coefficient } & Std. Error & t-Statistic & Prob. \\
\hline \hline \multicolumn{1}{c}{ C } & -1.378115 & 0.475290 & -2.899523 & 0.0050 \\
DAU? & 1.076547 & 0.081339 & 13.23532 & 0.0000 \\
PAD? & 0.662602 & 0.350953 & 1.888006 & 0.0634 \\
\multicolumn{1}{c}{ LETAK? } & -0.262280 & 0.303672 & -0.863695 & 0.3908 \\
\hline \hline R-squared & 0.813097 Mean dependent var & & 3.677887 \\
Adjusted R-squared & 0.801939 S.D. dependent var & & 1.541389 \\
S.E. of regression & 0.685981 Akaike info criterion & & 2.150981 \\
Sum squared resid & 31.52815 Schwarz criterion & & 2.309082 \\
Log likelihood & -72.43530 Hannan-Quinn criter. & & 2.213921 \\
F-statistic & 72.86887 Durbin-Watson stat & & 1.083983 \\
Prob(F-statistic) & 0.000000 & & \\
\hline \hline
\end{tabular}

Sumber: Data Diolah, 2019

Berdasarkan tabel 1, nilai koefisienpada variabel DAU sebesar 1,076547, variabel PAD sebesar 0,662602, dan variabel Letak pemerintahan sebesar -0,262280. Sementara untuk nilai probabilitas variabel DAU sebesar 0,0000, variabel PAD sebesar 0,0634dan variabel Letak pemerintahan sebesar 0,3908. Nilai probabilitas $<0,05$ menunjukkan bahwa hanya variabel variabel DAU berpengaruh signifikan. 
Jurnal Progres Ekonomi Pembangunan (JPEP)

Volume 5, Nomor 1. Tahun 2020

Page: $58-70$

http://ojs.uho.ac.id/index.php/JPEP

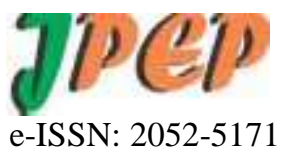

2. Pengujianmenggunakan Fixed Effect Models (FEM)

Dari hasil pengolahan Program E-views sebagai berikut:

\section{Tabel 2}

Hasil Estimasi Fixed Effect Models (FEM)

\begin{tabular}{lcrrr}
\hline \hline \multicolumn{1}{c}{ Variable } & \multicolumn{1}{c}{ Coefficient } & \multicolumn{1}{c}{ Std. Error } & \multicolumn{1}{c}{ t-Statistic } & \multicolumn{1}{c}{ Prob. } \\
\hline \hline C & 0.600826 & 0.714836 & 0.840508 & 0.4042 \\
DAU? & 0.731482 & 0.085852 & 8.520295 & 0.0000 \\
PAD? & 0.745673 & 0.367159 & 2.030929 & 0.0470 \\
LETAK? & -0.494863 & 0.602349 & -0.821555 & 0.4148 \\
\hline \hline R-squared & 0.917364 Mean dependent var & & 3.677887 \\
Adjusted R-squared & 0.895230 S.D. dependent var & & 1.541389 \\
S.E. of regression & 0.498921 Akaike info criterion & & 1.640391 \\
F-statistic & 41.44486Durbin-Watson stat & & 1.256079 \\
Prob(F-statistic) & 0.000000 & & \\
\hline \hline
\end{tabular}

Sumber: Data Diolah, 2019

Berdasarkan hasil analisis regresi data panel dengan pendekatan Fixed Effect Models (FEM) diatas dapat dilihat bahwa nilai probabilitastiap individu yang menunjukkan terdapat variabel signifikan yaitu variabel DAU dan PAD. Sedangkan Letak Pemerintahan tidak signifikan. Nilai Adjusted R-squared menunjukkan angka sebesar0,895230 dan nilai F-statistik sebesar 41.44486. Sedangkan nilai Probabilitas F-statistik sebesar 0,000000 yang memberikan arti bahwa model ini memiliki nilai signifikan.

\section{Pengujian menggunakanRandom Effect Models (REM)}

Dalam pendekatan penelitian ini, dengan data panel didasarkan adanya perbedaan intersep dan slope sebagai akibat adanya perbedaan antar individu.

Tabel 3

Hasil Estimasi Random Effect Models (REM)

\begin{tabular}{lrrrr}
\hline \hline \multicolumn{1}{c}{ Variable } & Coefficient & Std. Error & t-Statistic & Prob. \\
\hline \hline C & -0.749388 & 0.433007 & -1.730660 & 0.0881 \\
DAU? & 0.944829 & 0.070125 & 13.47348 & 0.0000 \\
PAD? & 0.724984 & 0.302899 & 2.393483 & 0.0195 \\
\multicolumn{1}{c}{ LETAK? } & -0.243831 & 0.291573 & -0.836259 & 0.4060 \\
\hline \hline R-squared & 0.755082 Mean dependent var & & 2.407868 \\
Adjusted R-squared & 0.740460 S.D. dependent var & & 1.168114 \\
S.E. of regression & 0.595097 Sum squared resid & & 23.72739 \\
F-statistic & 51.64017 Durbin-Watson stat & & 1.064421 \\
Prob(F-statistic) & 0.000000 & & \\
\hline \hline
\end{tabular}

Sumber: Data Diolah, 2019

Berdasarkan hasil analisis regresi dengan pendekatan RandomEffect Models (REM), dimana diperoleh nilai probabilitas variabel DAUsebesar 0,0000 dan variabel PAD sebesar 0,0195, dimana probabilitas kedua variabel tersebut $<0,05$, artinya kedua variabel tersebut memiliki pengaruh signifikan terhadap opportunistik penyusun anggaran (OPA). Sementara variabel Letak pemerintahan merupakan variabel yang tidak berpengaruh signifikan, dimana nilai probabilitas 
Jurnal Progres Ekonomi Pembangunan (JPEP)

Volume 5, Nomor 1. Tahun 2020

Page: $58-70$

http://ojs.uho.ac.id/index.php/JPEP

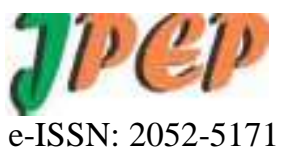

0,4060> 0,05. Sementara untuk nilai Adjusted $R$-squared menunjukkan nilai sebesar 0,740460 dan nilai F-statistik sebesar 51,64017. Sedangkan nilai probabilitas F-statistik sebesar 0,000000 yang memberikan arti bahwa model ini memiliki nilai signifikan.

\section{Penentuan Teknik Analisis Model data Panel}

\section{Uji Chow}

Uji Chow digunakan untuk memilih antara CEM dan FEM. Uji ini dilakukan setelah mengestimasi model CEM. Untuk lebih jelasnya hasil olah data uji chow dapat dilihat pada tabel berikut:

Tabel 4

Hasil Uji Chow

\begin{tabular}{|l|r|r|r|}
\hline Effects Test & Statistic & d.f. & Prob. \\
\hline Cross-section F & 6.423528 & $(11,56)$ & 0.0000 \\
\hline Cross-section Chi-square & 58.762459 & 11 & 0.0000 \\
\hline
\end{tabular}

Sumber: Data Diolah, 2019

Dari hasil tabel 5 nilai yang dihasilkan dalam distribusi statistik terhadap chi square berdasarkan hasil hitung dengan menggunakan E-viewsadalahsebesar 58,762459 dengan probabilitas yang dihasilkan 0,0000 yaitu menyatakan signifikan karena $<0,05$, sehingga statistik yang terjadi menerima $\mathrm{H} 1$ dan menolak $\mathrm{H} 0$, dimana dalam hal ini pemilihan model yang tepat untuk digunakan yaitu model fixed effects.

\section{Uji Hausman}

Uji Hausman digunakan untuk memilih antara model FEM dan REM. Uji ini dilakukan setelah dilakukan uji Chow dan terpilih model FEM. Untuk lebih jelasnya hasil olah data uji chow dapat dilihat pada tabel berikut:

\section{Tabel 5}

\section{Hasil Uji Hausman}

\begin{tabular}{|l|r|r|c|}
\hline Test Summary & Chi-Sq. Statistic & Chi-Sq. d.f. & Prob. \\
\hline Cross-section random & 32.320633 & 4 & 0.0000 \\
\hline
\end{tabular}

Sumber: Data Diolah, 2019

Berdasarkan tabel di atas menunjukkan nilai chi-squares sebesar 32,320633. Sedangkan nilai probabilitasnya $0,0000>0,05$, artinya dalam hal ini $\mathrm{H} 0$ ditolak dan $\mathrm{H} 1$ diterima, sehingga untuk pemilihan model yang akan tepat untuk digunakan pada penelitian ini yaitu modelFixed Effect Models (FEM).

\section{Uji Asumsi Klasik}

\section{Normalitas}

Uji normalitas dilakukan dengan membandingkan nilai probability Jarque-Bera dengan nilai alpha 5\%. Jika nilai probability Jarque-Bera lebih besar dari nilai alpha 5\%, maka data berdistribusi normal.

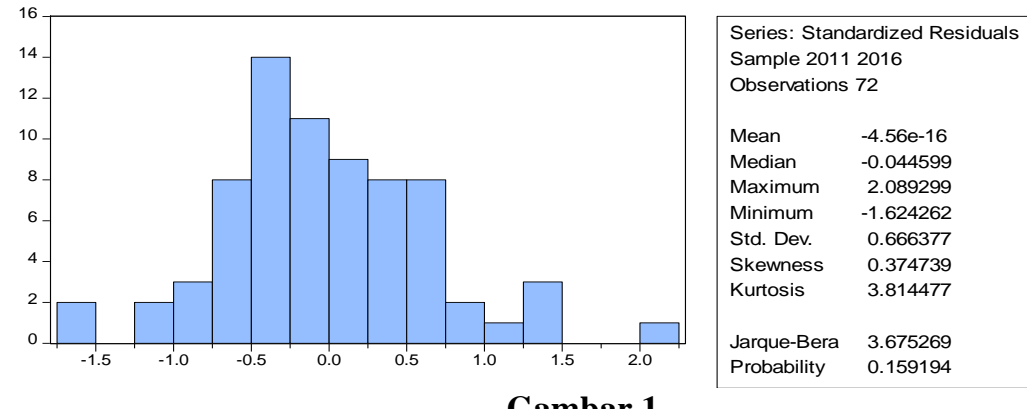

Gambar 1

Hasil Uji Normalitas 
Jurnal Progres Ekonomi Pembangunan (JPEP)

Volume 5, Nomor 1. Tahun 2020

Page: $58-70$

http://ojs.uho.ac.id/index.php/JPEP

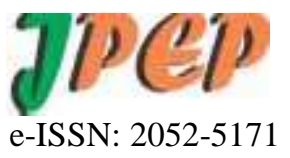

Berdasarkan gambar diatas, maka dapat disimpulkan bahwa data pada penelitian ini telah terdistribusi dengan normal, dimana nilai probability Jarque -Bera nya sebesar 0,159194>0,05.

\section{Heterokedasitas}

Uji heterokedasitas dilakukan dengan membandingkan nilai probability Likelihood ratio dengan nilai alpha 5\%. Jika nilai probability Likelihood ratio lebih besar dari nilai alpha 5\%, maka tidak mengandung gejala heterokedasitas.

\section{Tabel 6}

\section{Uji Heterokedasitas}

\begin{tabular}{|l|c|c|c|}
\hline & Value & Df & Probability \\
\hline Likelihood ratio & 4.746977 & 12 & 0.9659 \\
\hline
\end{tabular}

Sumber: Data Diolah, 2019

Berdasarkan tabel 8 di atas, menunjukkan nilai probability Likelihood sebesar 0,9659<0,05. Sehingga dapat disimpulkan bahwa data penelitian ini tidak terjadi heteroskedastisitas.

\section{Koefisien Determinasi (R-Squared)}

Berdasarkan tabel 2 menunjukkan nilai R-Squared sebesar 0,9174 dan nilai Adjusted R-square sebesar 0,8952. Artinya, variabel OPA mampu dijelaskan oleh variabel DAU, PAD dan Letak pemerintahan sebesar $89,52 \%$, dan sisanya sebesar $10,48 \%$ dijelaskan oleh variabel lain diluar model penelitian ini.

\section{Analisis Regresi Fixed Effect Models (FEM)}

Berdasarkan hasil uji Chow dan uji Hausman, maka model yang digunakan untuk membuktikan hipotesis yang telah diajukan dalam penelitian ini adalah "Model Regresi Fixed Effect Models (FEM)". Dari hasil estimasi regresi data panel dengan Fixed Effect Models (FEM) dapat dilihat pada tabel berikut:

\section{Tabel 7}

Hasil Regresi Model FEM

\begin{tabular}{crrrr}
\hline \hline Variable & \multicolumn{1}{l}{ Coefficient } & \multicolumn{1}{l}{ Std. Error } & \multicolumn{1}{c}{ t-Statistic } & \multicolumn{1}{c}{ Prob. } \\
\hline \hline C & 0.600826 & 0.714836 & 0.840508 & 0.4042 \\
DAU? & 0.731482 & 0.085852 & 8.520295 & 0.0000 \\
PAD? & 0.745673 & 0.367159 & 2.030929 & 0.0470 \\
LETAK? & -0.494863 & 0.602349 & -0.821555 & 0.4148 \\
\hline \hline
\end{tabular}

Sumber: Data Diolah, 2019.

Berdasarkan Tabel 7, maka dapat dilakukan Uji Hipotesis (Uji t) pada masing-masing variabel bebas terhadap perilaku oportunistik sebagai berikut

\section{Variabel DAU}

Dari hasil estimasi, di dapatkan nilai t-hitung sebesar 8,520295 dan jika dilihat dari besarnya nilai probabilitas DAU yaitu 0,0000 sehingga probabilitas DAU lebih kecil dari nilai alpha 5\% (0,0000 $<0,05)$ maka disimpulkan bahwa variabel DAU memiliki pengaruh yang signifikan dan juga berpengaruh positif terhadap OPA yang di tunjukkan oleh koefisien regresi sebesar 0,731482.

\section{Variable PAD}

Dari hasil estimasi, di dapatkan nilai t-hitung sebesar 2,030929 dan jika dilihat dari besarnya nilai probabilitas PAD yaitu 0,0470 sehingga probabilitas PAD lebih kecil dari nilai alpha 5\% (0,0470 $<0,05)$ maka disimpulkan bahwa variabel PAD memiliki pengaruh yang signifikan dan juga berpengaruh positif terhadap OPA yang di tunjukkan oleh koefisien regresi sebesar 0,745673. 
Jurnal Progres Ekonomi Pembangunan (JPEP)

Volume 5, Nomor 1. Tahun 2020

Page: $58-70$

http://ojs.uho.ac.id/index.php/JPEP

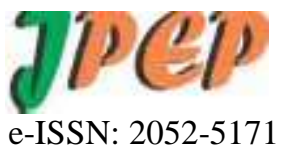

\section{Jenis dan Letak Pemerintahan}

Dari hasil estimasi, di dapatkan nilai t-hitung sebesar -0,821555 dan jika dilihat dari besarnya nilai probabilitas JENIS DAN LETAK yaitu 0,4148 sehingga probabilitas JENIS DAN LETAK lebih besar dari nilai alpha 5\% $(0,4148<0,05)$ maka disimpulkan bahwa variabel JENIS DAN LETAK memiliki pengaruh yang tidak signifikan dan juga berpengaruh negatif terhadap OPA yang di tunjukkan oleh koefisien regresi sebesar -0,494863.

\section{Pembahasan}

\section{Pengaruh DAU terhadap Perilaku Oportunistik Penyusun Anggaran}

Berdasarkan hasil analisis penelitian, menunjukkan bahwa variabel Dana Alokasi Umum berpengaruh positif dan signifikan terhadap Perilaku Oportunistik Penyusun Anggaran dengan nilai t-hitung sebesar 8,520295 dan besarnya nilai probabilitas DAU sebesar 0,0000 $(0,0000<0,05)$.

Hal ini mengindikasikan bahwa kenaikan variabel Dana Alokasi Umum maka Perilaku Oportunistik Penyusun Anggaranakan naik. Oleh karena itu besar kecilnya DAU dapat mempengaruhi terjadinya perilaku oportunistik penyusun anggaran. DAU ini sebenarnya adalah dana yang bersumber dari pendapatan APBN yang dialokasikan dengan tujuan pemerataan kemampuan keuangan antar daerah untuk mendanai kebutuhan daerah dalam rangka pelaksanaan desentralisasi. Dengan demikian, terjadi transfer yang cukup signifikan didalam APBN dari pemerintah pusat ke pemerintah daerah. Pemerintah daerah secara leluasa dapat menggunakan dana ini untuk memberi pelayanan yang lebih baik kepada masyarakat atau untuk keperluan lain yang tidak penting.

\section{Pengaruh PAD terhadap Perilaku Oportunistik Penyusun Anggaran}

Berdasarkan hasil analisis penelitian, menunjukkan bahwa variabel Pendapatan Asli Daerah berpengaruh positif dan signifikan terhadap Perilaku Oportunistik Penyusun Anggaran dengan nilai t-hitung sebesar 2,030929 dan jika dilihat dari besarnya nilai probabilitas PAD yaitu 0,0470 sehingga probabilitas PAD lebih kecil dari nilai alpha $5 \%(0,0470<0,05)$ Hal ini mengindikasikan bahwa kenaikan variabel Pendapatan Asli Daerah maka Perilaku Oportunistik Penyusun Anggaran akan naik. Pembuktian secara empiris ini bahwa upaya pihak berwenang dalam melakukan perilaku oportunistik mempengaruhi keputusan alokasi anggaran belanja di APBD untuk memenuhi kepentingan pribadinya maupun secara berkelompok. Oleh karena itu perubahan pendapatan asli daerah berpengaruh terhadap perilaku oportunistik penyusun anggaran tidak dapat ditolak, dimana bahwa PAD merupakan jalan bagi pihak berwenang untuk melakukan "Political Corrution" dalam kerangka regulasi yang sah (legal corruption) dapat dibuktikan ketika perubahan atau kenaikan anggaran/ target PAD digunakan sebagai dasar untuk melakukan alokasi tambahan belanja.

Pendapatan asli daerah sebenarnya dipungut berdasarkan peraturan daerah sesuai dengan peraturan perundang-undangan, pendapatan asli daerah sebagai sumber penerimaan daerah yang perlu terus ditingkatkan agar dapat menanggung sebagian belanja yang diperlukan untuk penyelenggaraan pemerintah dan kegiatan pembangunan yang setiap tahun meningkat sehingga kemandirian otonomi daerah yang luas, nyata dan bertanggung jawab dapat dilaksanakan (Nurlan Darise, 2006:43).

\section{Pengaruh Jenis dan Letak Pemerintahan terhadap Perilaku Oportunistik}

Berdasarkan hasil pengujian yang dilakukan di ketahui bahwa Jenis dan Letak Pemerintahan berpengaruh negatif dan tidak signifikan pada perilaku Opportunistik Penyusun Anggaran dengan nilai t-hitung sebesar -0,821555 dan jika dilihat dari besarnya nilai probabilitas jenis dan letak yaitu 0,4148 sehingga probabilitas jenis dan letak lebih besar dari nilai alpha $5 \%$ $(0,4148<0,05)$ maka disimpulkan bahwa variabel jenis dan letak memiliki pengaruh yang tidak signifikan dan juga berpengaruh negatif terhadap OPA yang di tunjukkan oleh koefisien regresi 
Jurnal Progres Ekonomi Pembangunan (JPEP)

Volume 5, Nomor 1. Tahun 2020

Page: $58-70$

http://ojs.uho.ac.id/index.php/JPEP

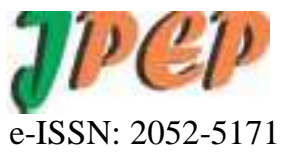

sebesar -0,494863.Hipotesis 4 (H3) menunjukkan bahwa variabel Jenis dan Letak Pemerintahan berpengaruh positif dan signifikan terhadap Perilaku Oportunistik Penyusun Anggaran. Berdasarkan hasil pengujian yang dilakukan di ketahui bahwa variabel Jenis dan Letak Pemerintahan berpengaruh negatif dan tidak signifikan terhadap Perilaku Oportunistik Penyusun Anggaran. Oleh karena itu perilaku oportunistik penyusun anggaran dapat dilakukan tidak tergantung pada status suatu daerah, baik kabupaten maupun kota.

Jenis dan Letak Pemerintahan dapat di samakan sebagai status daerah, dimana pandangan bahwa status daerah mempengaruhi kelengkapan pengungkapan informasi penggunaan anggaran dikarenakan adanya perbedaan karakteristik masyarakat dan struktur pendapatan antar daerah. Secara teori perbedaan ini dapat berimplikasi pada kontrol sosial yang berbeda pula (Abdullah, 2004). Kontrol sosial pada penduduk kota cenderung lebih kuat, sehingga Pemerintah Daerah yang berstatus sebagai Kota akan cenderung mematuhi standar anggaran. Namun hasil dari penelitian ini menemukan bahwa kota kendari dan kota baubau masuk dalam daerah yang melakukan tindakan korupsi bersama dengan kabupaten-kabupaten lainnya di sulawesi tenggara. Seyogyanya Kota Kendari dan kota baubau mampu menjadi contoh ataupun panutan bagi kabupaten-kabupaten lain yang ada di Sultra dalam hal penanganan perilaku opportunistik anggaran jika dilihat dari sisi statusnya sebagai kota yang memiliki sumber daya yang jauh lebih baik dari kabupaten.

Pengaruh jenis dan letak pemerintah daerah dalam penelitian ini memberikan bukti bahwa intensitas perilaku oportunistik penyusun anggaran tidak berkaitan dengan status daerah sebagai kota atau kabupaten. Pandangan bahwa perilaku oportunistik penyusun anggaran di tingkat Kabupaten lebih besar dari pada di tingkat Kotamadya bersumber dari anggapan bahwa social control dari stakeholders di luar pemerintahan terhadap pelaksanaan pelayanan publik dan perilaku anggota legislatif tidak terbukti.

\section{KESIMPULAN DAN SARAN}

\section{Kesimpulan}

1. Variabel DAU berpengaruh signifikan dan positif terhadap perilaku Oportunistik Penyusun Anggaran di Kabupaten/Kota se Sulawesi Tenggara. kenaikan variabel Dana Alokasi Umum maka Perilaku Oportunistik Penyusun Anggaran akan naik. Oleh karena itu besar kecilnya DAU dapat mempengaruhi terjadinya perilaku oportunistik penyusun anggaran.

2. Variabel pendapatan asli daerah berpengaruh signifikan dan positif terhadap perilaku oportunistik penyusun anggaran. kenaikan variabel Pendapatan Asli Daerah maka Perilaku Oportunistik Penyusun Anggaran akan naik. Pembuktian secara empiris ini bahwa upaya pihak berwenang dalam melakukan perilaku oportunistik mempengaruhi keputusan alokasi anggaran belanja di APBD untuk memenuhi kepentingan pribadinya maupun secara berkelompok.

3. Variabel jenis dan letak pemerintahan berpengaruh tidak signifikan dan negatif terhadap perilaku oportunistik penyusun anggaran. perilaku oportunistik penyusun anggaran dapat dilakukan tidak tergantung pada status suatu daerah, baik kabupaten maupun kota..

\section{Saran}

1. Pemerintah daerah hendaknya lebih meningkatkan kualitas penyusunan anggaran dengan mengutamakan alokasi belanja sesuai kebutuhan masyarakat, transparansi anggaran serta menerapkan pengawasan mulai dari proses perencanaan anggaran. Dibutuhkan pula kebijakan penggunaan dana alokasi umum sehingga dapat digunakan secara efektif dan efisien oleh pemerintah daerah untuk peningkatan pelayanan kepada masyarakat. Kebijakan penggunaan dana tersebut sudah seharusnya pula secara transparan dan akuntabel.

2. Dengan adanya otonomi daerah diharapkan semua daerah di Provinsi Sulawesi Tenggara mampu melaksanakan semua urusan pemerintahan dan pembangunan dengan bertumpu pada 
Jurnal Progres Ekonomi Pembangunan (JPEP)

Volume 5, Nomor 1. Tahun 2020

Page: $58-70$

http://ojs.uho.ac.id/index.php/JPEP

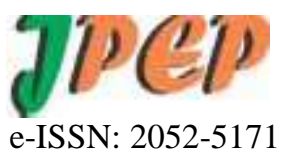

Pendapatan Asli Daerah (PAD) yang dimilikinya. Berkaitan dengan hal tersebut optimalisasi sumber-sumber Pendapatan Asli Daerah (PAD) perlu dilakukan untuk meningkatkan kemampuan keuangan daerah.

3. Berdasarkan nilai koefisien determinasi sebesar 0,8952, menunjukkan bahwa masih terdapat $10,48 \%$ pengaruh variabel lain yang mampu menjelaskan variasi variabel perilaku oportunistik penyusun anggaran, maka disarankan bagi peneliti selanjutnya untuk meneliti faktor lain yang berpengaruh terhadap perilaku oportunistik penyusun anggaran.

4. Aspek metodologi pada penelitian ini belum mampu mengungkapkan sepenuhnya beberapa persoalan yang mungkin penting untuk menggambarkan perilaku penyusun anggaran, sehingga perlu dikembangkan suatu daftar pertanyaan lengkap (kuisioner) yang dapat mengukur persepsi pihak - pihak yang terlibat pada penyusunan anggaran.

5. Penelitian selanjutnya dapat memperbaiki pengukuran nilai OPA dengan lebih fokus pada sektor yang memiliki belanja langsung dengan nilai yang besar, mengingat kecenderungan OPA terjadi pada belanja langsung dibandingkan belanja tidak langsung.

\section{DAFTAR PUSTAKA}

Abdullah, S. 2012. Perilaku OportunistikLegislatif danFaktor-Faktor Yang Mempengaruhinya: Bukti Empiris dari Penganggaran Pemerintah Daerah di Indonesia.Ringkasan Disertasi. Yogyakarta: Universitas Gajah Mada.

Abdullah,S.dan Asmara, J.A. 2006. Perilaku Oportunistik Legislatif Dalam Penganggaran Daerah: Bukti Empiris atas Aplikasi Agency Theory di Sektor Publik. Jurnal Simposium Nasional Akuntansi 9. Padang23-26 Agustus.

Bartolini, D., and Santolini, R. 2007. FiscalRules and TheOpportunistic Behaviour of The Incumbent Politician: Evidence From Italian Municipalities. Working Paper. Institute of Local Public Finance February2007.

Eisenhardt,K.M.1989. Agency theory: Anassessmentandreview. Academyof Management Review14 (1): 57-74.

Hagen,J.V.2002. Fiscalrules, fiscal institutions, and fiscal performance. The Economic and Social review33(3): 263-284.

Halim, A. dan Abdullah, S. 2006. Hubungan dan Masalah Keagenan di Pemerintahan Daerah: Sebuah Peluang Penelitian Anggaran dan Akuntansi. Jurnal Akuntansi Pemerintah2(1):5364.

Jensen, M.C. and W.H. Meckling.1976. Theory of The Firm: Managerial Behavior, Agency Costand Ownership Structure. Journa lof Financial Economics.Vol.3.No.4.pp.305-360.

Jumaidi, L.T.2014. Perilaku Legislatif dalam Praktik Penganggarand engan Pendekatan NilaiNilai Kearifan Lokal. Jurnal Simposium Nasional Akuntansi 17 Mataram Lombok 24-27 September 2014.

Latifah, N.P. 2010. Adakah Perilaku Oportunistik dalam Aplikasi Agency Theory di Sektor Publik?. Fokus Ekonomi Vol. 5 No. 2 Desember2010: 85 - 94.

Lupia, A. and Mc Cubbins, M.2000. Representation orabdication? Howcitizens use institution stohelp delegation succeed. European Journalof Political Research37:291-307.

Mardiasmo. 2002. Otonomi dan Manajemen Keuangan Daerah.Yogyakarta: PenerbitAndi.

Maryono,R.2013. Pengaruh Perubahan Dana Alokasi Umum Terhadap Perilaku Oportunistik Legislatif Dalam Penganggaran Daerah. E-Jurnal UNP.

Mauro, P.1998. Corruption and the composition of government expenditure. Journal of Public Economics 69:263-279. 
Jurnal Progres Ekonomi Pembangunan (JPEP)

Volume 5, Nomor 1. Tahun 2020

Page: $58-70$

http://ojs.uho.ac.id/index.php/JPEP

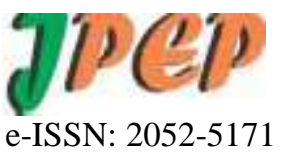

Oktririniatmaja, R. 2011. Pengaruh Pendapatan Asli Daerah, Dana Alokasi Umum dan Dana Alokasi Khusus terhadap Pengalokasian Anggaran Belanja Modal dalam Anggaran Pendapatan dan Belanja Daerah Pada Pemerintah Daerah Kabupaten/Kota di Pulau Jawa, Sulawesi Tenggara dan Nusa Tenggara. E-Journal Universitas Sebelas Maret.

Raghunan dan, M. Ramgulam, N and Raghunan dan, K.2012. Examining the behaviouralaspectsofbudgetingwithparticularemphasisonpublicsector/ servicebudgets. International Journal of Business and Social Science3(14).

Sujaie, A.F.2013. Oportunisme Perumus Kebijakan Anggaran dalam Penyusunan APBD Provinsi Jawa Timur Tahun 2013: Fenomena dalam Pelaksanaan Belanja Hibah dan Bansos. EJournal UGM.

Sularso,H., Restianto, Y.E. dan Istiqomah, A.E. 2014. Determinan Perilaku Oportunistik Penyusunan Anggaran (Studipada Kabupaten/KotadiJawa Tengah). Jurnal Simposium Nasional Akuntansil 7 Mataram Lombok 24-27 September2014.

Suryarini,T.2012. Perilaku Oportunistik Legialtaif dalam Penganggaran Daerah: Bukti Empirisatas Aplikasi Agency Theory di Sektor Publik. Jurnal Review Akuntansi dan KeuanganVol. 2 No. 1 April2012.

Tanzi,V.and Davoodi, H.2002. Corruption, public investment, and growth, Governance,Corruption, \&EconomicPerformance. Washington, D.C.: International Monetary Fund.

Yusuf Jaya Saputra,2019. Pengaruh DAU, PAD, SILPA, Jenis Dan Letak Pemerintahan Terhadap Perilaku Oportunistik Penyusun Anggaran di Kabupaten/Kota Se-Sulawesi Tenggara. 